\title{
Chapter 7 Patrocinio 101
}

It remains - to remain? -

The flesh wounded. There is a scar.

And the mind - the mind? - wounded

wounded? No, there is no wound.

If there were one there would be blood.

There is a scar. No, Neither.

If there were a scar, it would be evident. They do not always show, they say.

Certain words are used instead of others, they say. When there are not enough words. Better when there's nothing. ${ }^{1}$

Chantal Maillard, Hilos (2007)

I stand in the middle of the room, my hand pressing down on top of the round dining table. My five fingers are not enough anymore to count my age. Six years old, three feet tall, two eyes closed, and one mouth shut, I stand stiff, straight, my free right hand tightly squeezing my mother's. The hot sterilized sewing needle pierces my pearly earlobe. Inside my mouth I scream, as a flood of salty tears washes over

1 Permanece-permanecer?-la carne

herida. Hay cicatriz.

Y la mente-la mente?-herida.

Herida? No, no hay herida. Si

la hubiese habría sangre. Hay

cicatriz. Tampoco.

Si hubiese cicatriz, sería

Evidente. No siempre se ven, dicen.

Ciertas palabras se utilizan

en vez de otras, dicen. Cuando

no hay palabras suficientes.

Mejor cuando no hay

cosa. Chantal Maillard, Hilos (Barcelona: Tusquets, 2007), 15. 
my eyes. My aunt pulls the alcohol-laced thread through the tiny opening as if stitching a label to my skin.

\title{
On the Point of a Needle
}

\author{
Night of four moons \\ and a single tree \\ On the point of a needle \\ There's my love, \\ Spinning! ${ }^{2}$
}

My aunt Patro is my godmother and my mother's cousin. A seamstress by night, and a butcher by day, she is very skilled with knives of various sizes, scissors, pins, and needles. The perfect piercing artist. She pierces with her voice too.

Ya está, Ya está, Ya está.../ There, there, there...
eso no es na!/ That is nothing!
Qué valiente es mi niña/ My Little girl is so brave
$y /$ and
qué guapa va a estar/She will be so beautiful
con sus zarcillos nuevos/with her new earrings
p’a su primera comunión!/ for her First Communion

When the ordeal is over, a storm of kisses drenches my face. They are Andalusian kisses, accompanied by a chorus of chirping birds.

Patro was born on September 12, 1917, in Granada, one of five siblings. When she was four years old, she was gifted to the childless Escribano family, the owners of the butcher shop where her father worked. In those days, it was not uncommon for spare children to be given to relatives or others in an informal kind of adoption. This was done sometimes out of economic necessity and other times as a token of compadrazgo, or kinship.

Patro refers to her adoptive parents as her "Aunt" and "Uncle," even though they were not blood relatives. She is not clear on the details of the transaction, but this was not some hidden family secret. Patro still saw her biological parents and siblings-they all lived in the same neighborhood and her father continued to work in the butcher shop-and thought nothing unusual about this arrangement. As she

2 Federico García Lorca, Selected Poems, trans. Martin Sorrell (Oxford: Oxford University Press, 2007), 91-93. 
tells it, her "aunt" had taken a liking to her when both families lived in the same building. When her aunt and uncle moved to a new house, Patro, along with the furniture, went with them:

When they bought the house in the Escudo del Carmen...that was when I left with them, I was only four years old. Because my aunt had no children and I was a very sweet little girl, she loved me very much. When we lived in the same building I would say... 'Oh my auntie is coming'...and filled the jar with fresh water....

Moving to the Escribano house took Patro out of the crime-ridden Manigua neighborhood and also provided her with a more comfortable life. "I used to go in the afternoons to see my aunt's sister at the 'Thirty-two' [restaurant] where we had our afternoon snack. Then, some days in the summer we would visit that sister in the village of Zubia where she owned a cortijo (farmhouse). Well, we would go to the cortijo in the summer afternoons to visit for a little while. We always went in the afternoon and we had to ride the trolley car...of course!"4

Patro loved her aunt, accompanying her everywhere, even the butcher shop where her father still worked. An outgoing, social girl, she preferred the vibrancy of the market to the drudgery of school. When she turned twelve, she asked her aunt if she could quit school to help out in the store. "All I wanted was to sell. I told my aunt to let me sell lemons and parsley." she extends her tiny hand towards me, turns it up, making a little bowl shape with her fingers where she holds an imaginary lemon, while with the other hand, she pretends to braid a strand of parsley. "... It would cost a 'perrilla' or a 'gorda ${ }^{5}$.... And so that's it, I liked to sell. I began selling in the market next to the butcher shop." 6

When she turned fifteen, a handsome young man from the neighborhood, Juan, started noticing her. Her aunt was not so keen on the advances of a rodaballo, a turbot, she called him, nine years older than Patro, but there was little she could do to prevent the two lovebirds from liking each other. As were the rules of courtship, Juan and Patro could not talk to each other without a third party present at all times. That responsibility fell to Patro's younger brother, Paco.

I talked to him [Juan] through an iron gate at the Escudo del Carmen house, and sometimes someone came in and I ran up the stairs to the first floor... and he would push and try to slip his foot in to hold the door ajar.... That would scare me, so he would quickly retreat.... One derribo de la Manigua," June 16, 2015. https://granadablogs.com/terecuerdo/2015/06/16/comi enza-el-derribo-de-la-manigua/\#more-1342

4 Patrocinio Martínez Sánchez, audio recording by author, Granada, December 2012.

5 Currency units that do not amount to even a penny.

6 Patrocinio, recording, 2012. 
day my uncle showed up...I don't know why or what might have happened for him to all of a sudden show up but I darted up the staircase while my husband [to be] stayed downstairs. And then when carnival time came, and everyone in masks, that's when my Juan finally asked my uncle's permission to climb the stairs to talk to me. ${ }^{7}$

Figure 16: Patro and Juan

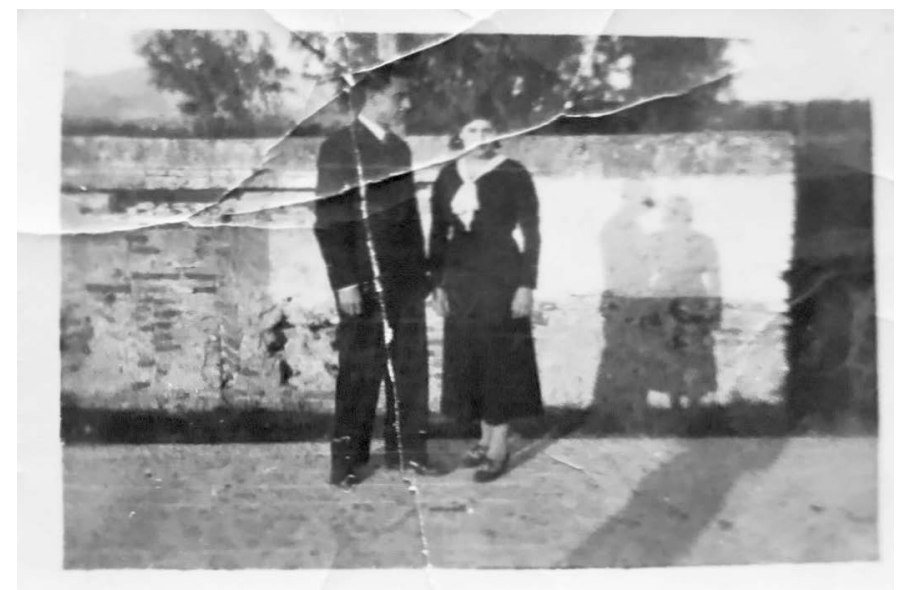

Patro and Juan got married after four years of courtship. She was nineteen. Their wedding took place in the spring of 1936, just prior to the beginning of the Spanish Civil War. They got married in the San Ildefonso Church in the Triunfo district where Patro's parents lived, though the bride departed to the church from her aunt and uncle's home in the Escudo del Carmen. She recalled her nuptials fondly.

"My husband gave me 20 duros $^{8}$ for both my wedding dress and the dress for the day after. I also had enough to buy fabric to make some curtains," she recalled with pride. "The wedding dress cost one duro per meter...because it was sateen...so shiny and beautiful...the sleeve required a least one meter of fabric as it was all gathered at my wrist so." She wraps her fingers around her tiny wrist to demonstrate, as if she were touching the sateen once more. "And my veil...and my bouquet...." She remembers how Juan also paid thirteen duros for a six-car procession to transport the wedding party from the Escudo del Carmen Street to the church. In a melodic tone she loudly sings, "SIX CARS." 
Figure 17: Patro and Juan's wedding

photo

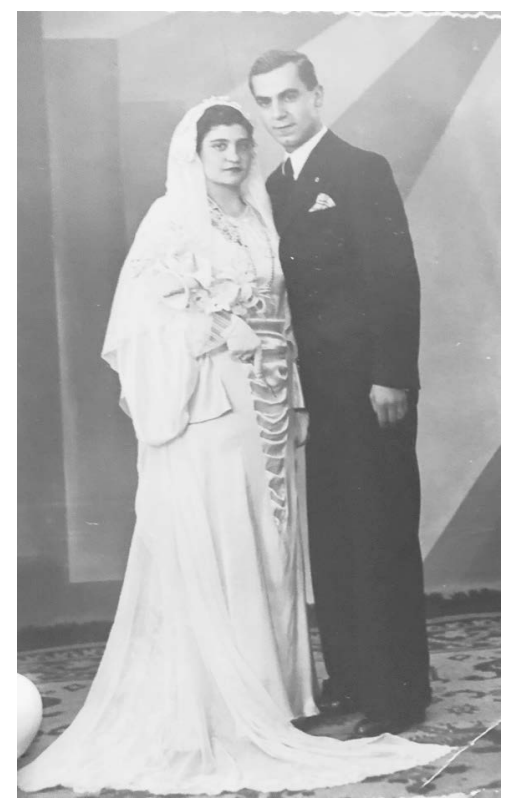

They moved into a one-bedroom pied-a-terre in the Boqueron district, which she recalled warmly: "The house...well I furnished a very suitable home. Look, ...there was my bed, which I still have! That one will remain my bed until I DIE!!... My armoire and two stone-topped bedside tables.... And one of those old washbasins with a water jar...have you seen those? I also had sewn myself a beautiful peignoir, which by the way...there is a history behind that too... a lady who lived on the Aranda's street made me this peignoir along with some embroidered linens and so on.... Later, I made a blouse out of it, a vivid pink sateen piece with brown embroidered embellishments...." She paused for an instant. "You see, I also had a bridal bedcover...a dining room table with its tablecloth...two pedestals with their doilies, two grid chairs, and my sister-in-law Indalecia made me some round cushions with some Chinese designs.... My sister-in-law was so talented.... And then in the kitchen we had an espetera, the cantarera, the table...that's thanks to Tito Emilio who crafted all those household things for me.... And also, one of those little pantry cupboards. And a trunk for my clothes." 9 
The accumulation of household furnishings and fittings at the time of marriage was mostly the responsibility of the bride and was supposed to portend a successful union. While modest, their home was more than adequate for a skilled worker and his wife. Juan was a cook who expected his young bride to stay at home and forget about butcher shops or selling in the market.

Juan had five siblings: three sisters, Indalecia, Virtudes, and Dolores, and two brothers, Nicolás and Miguel. Indalecia was dear to Patro. They were almost the same age. Originally, Indalecia was to marry her boyfriend, a mailman, before Patro and Juan, but they decided to wait. She sadly remembers how Indalecia lost her boyfriend in the early days of the civil war. The war was not easy on Patro either. She got pregnant right away, and Juan was sent to Sevilla to serve as cook in the home of General Queipo de Llano, the brutal commander of the Nationalists' southern forces.

Patro, a woman who was never particularly interested in politics, doesn't seem to grasp the implications of her husband working for the general responsible for the massacre of so many Spaniards during the civil war. She spoke about Juan's position as if it were just another deployment: "They picked him and another guy up and took them to Sevilla to cook for Queipo. He told me they [The Queipos] were very good people...especially his wife, buenísima. But my husband found himself with the other guy who was not trustworthy and...my husband got scared, sick. He obsessed about what the other guy might do.... If something happened to Queipo they might blame it on the cook for poisoning him or something. My husband got a bladder infection from worrying. The General's wife, who was very sweet, had a conversation with her husband and...she went ahead and gave Juan FIVE DUROS!! and sent him back to me in Granada. I remember how cousin Miguel was coming down the street yelling, 'he is coming, he is coming, Juan is coming!! And suddenly, my husband appeared at the front door... He, poor man, looked so sick...THAT WOMAN gave him five duros!!...for the trip back because she was so kindhearted.... He [Juan] had had a talk with her...and the other scoundrel stayed behind.... ${ }^{10}$

I am listening in silence, trying to process in my head how to render the story, her story, that now is mine to tell and which suddenly makes the enemy a close personal subject. The alien nature of evil suddenly enters the room, and its ghost sits in on our conversation. Ronald Fraser tells us how "all those denounced by 'law-abiding citizens' as assassins, left-wingers, trouble-makers, non-churchgoers were certain to be court-martialed."11 There is no question Juan was terrified to be working for someone like Queipo. However, the way he managed to return to

10 Patrocinio, recording, 2012.

11 Ronald Fraser, Blood of Spain: An Oral History of the Spanish Civil War (New York: Pantheon, 1979), 158 . 
his pregnant wife in late December 1937 with money in his pocket is suspicious. Patro continued, "My husband did not belong to any political party, unlike his sister Indalecia.... My sister-in-law was into politics. She was with the workers, but my husband was not. One night, as he approached his house, Juan saw some of the workers meeting on the terrace, and he told them, 'Oh you're going to bring us ruin.' But my husband did not turn them in.... He went into his house...I mean he was so righteous. And then they caught them...that was terrible. Aunt Indalecia participated in the Casa del Pueblo persecution, as it was known... But as she did not know how to sign her name, nothing happened...otherwise, God knows what would have happened to her. And yet she had a boyfriend who was a postman, who ran with people who were you know [she implied they were leftists]...in Casa del Pueblo or in the bar...they would meet, and they would talk. My dear...and they took thirteen postmen and in twenty-four hours they shot them. My sister-in-law went every day to the cemetery... and we were going with her...with my children, and I went to the cemetery myself. The awful thing that happened...that she was going to get married."

Like all families who lived through the Spanish Civil War, there are secrets that do not easily give themselves up. I had never heard about Juan's involvement with Queipo de Llano during the war, or the Casa del Pueblo persecution in which my aunt's sister-in-law, one of the collaborators, was somehow spared on a technicality. Patro takes all these events at face value, never questioning the role her husband played.

As with many Spanish families in the south, loyalties were often split. Patro had been adopted into the right-wing Escribano family. Her memories of workers out to harm her adoptive relatives, owners of various enterprises, show a distinct right-wing bias. To her, the ones who just happened to disappear in the early years of the regime, some from her own family, were being indiscrete or worse, disloyal.

"I lived with the Escribanos, and you would hear them," Patro recalled. "I do not say that Franco was behind it, but there were many abuses...hatred and people being killed and blaming Franco. The tito of Aunt Consuelo's husband, you know your mother's sister...he was a man who talked a lot....and they took him out of the way...left him on the highway. And yet he had a brother who was pro-Franco. But because he spoke...one of those men who talks and talks and doesn't know what he is saying...with his eight children...they took him out of the way."

As Patro and Juan reunited and welcomed their first child in the winter of 1938, they still had to endure another year of war. Their marriage would last only seven more years. Seven more years, three more children, and twenty-four hours of agony. 


\title{
He Died at Dawn
}

\author{
My husband. Gone, \\ gone, gone, GONE. \\ white little darling face. \\ Green, purple, red \\ All of his body \\ gone, gone. $^{12}$
}

"Within twenty-four hours he was dead," she shared. "That photo, niña, HE DID NOT SEE, qué lástima de mi marído! Oh, my poor husband!" Juan had filed some paperwork to get an apartment in the new Figares district. The government had built some affordable housing for large families. Having a minimum of four children qualified them for the petition. As part of the paperwork, the family had their picture taken.

\section{Figure 18: Patro and Juan with three of their four children}

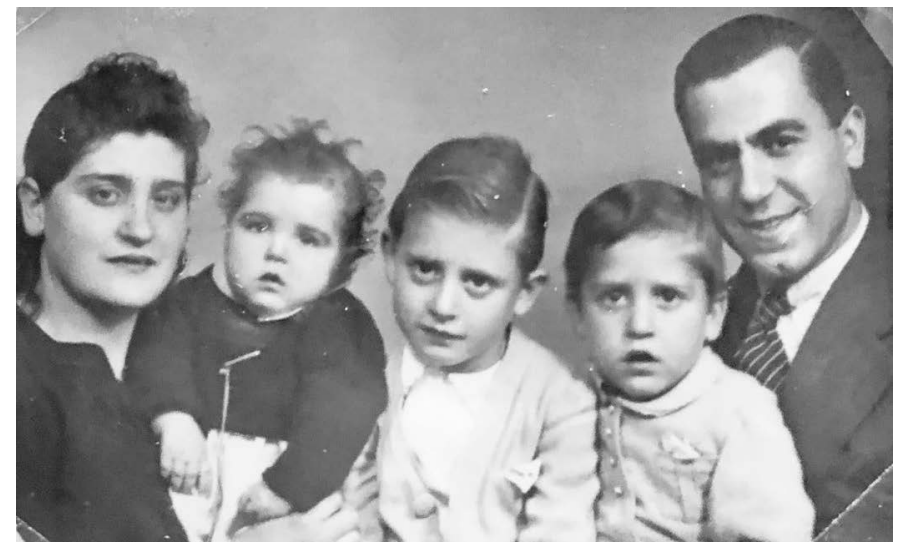

"He got septicemia. It seems that he cut himself working, you know. He must have cut himself with a can, and people started to say he got tetanus...no, no, no...HE DIED of septicemia.... They treated the wound...in his hand...but that thing was bad. They prescribed some pills and all day long he took those pills and retched at night...so very sick. I did not know what had taken over him, I was so young.... And then something started to show in his arm. My husband knew he was dying. I cannot forget those patches all over.... [she touched her arm up from her hand 
to her shoulder] He kept looking at those patches crying... 'do not look at them anymore.' The doctor was going to return in the morning to amputate the arm. My husband told me, 'You will have to return to sell [in the market].' I remember those last words. At nine in the morning the doctor came to take him to the hospital but by then he was already dead. My two little boys stood shivering in their undershirts, next to the bed. The neighbors came to see...as is customary...they laid him on the ground.... What a tragedy! In the evening...they took him to the cemetery. Only a little bit of his face remained white. The rest was black.... He was 38 years old and I...not 29 yet. [long silence] With four children."13

Patro was alone now. Her parents were taking care of one of her siblings, Pepe, the youngest brother, sick with tuberculosis, making it impossible for her to move back home. "Yes, my husband told me, 'You will sell;' it was my destiny," she remembered. "Within a year of his passing I was in the market. But first I started sewing. In our neighborhood, down the street there was this factory where they made overalls.... I started sewing overalls for them at home on my sewing machine because the pension I received did not cover all our needs. ${ }^{14}$ I received 468 pesetas, ${ }^{15}$ three duros ${ }^{16}$ which gave us enough to eat but not much more. People would ask me, 'What are you going to do with four kids? How will you survive? You surely will place the older ones [in an orphanage]....' And I said, all right, while I have things to sell in the house, we'll see about that."

"I couldn't survive on only three duros. NO WAY!! So I worked. I used to pick up the materials in the factory and sometimes Amelia, my neighbor, also a widow, would help, and the two of us made a little extra money. I remember how one day she came home all agitated because unintentionally she had cut one of the pieces wrong and so was panicked we would not get paid. I told her not to say a thing. Then, I folded all the pieces very nicely and put the defective one in between the good ones."

"I also remember how one day, another neighbor, Maria's husband, the coal worker, sold me fifteen duros of coal, and I took it to my living room and threw it on the floor and re-sold it to the neighbors! ME!! In my own house. I was not going

13 Patrocinio, recording, 2012.

14 Juan died in 1946.

15 After 1939, the Bank of Spain's objectives were set by the Francoist Ministry of Finance. Spain was excluded from the Marshall Plan and implemented autarchy or self-sufficient economy. After the Pact of Madrid in 1953 with the US, Spain wasn't able to escape the misery of the postwar years, the 1940s, known as the Hunger years. In 1959 the exchange for \$1 was 60 pts. This was thirteen years after Patro became a widow. On the financial history of the National Spanish Bank see Pablo Martin Aceña, The Banco de España, 1782-2017: The History of a Central Bank, in Estudios de Historia Económica, 73 (2017). https://www.bde.es/f/webbde/SES/Secciones /Publicaciones/PublicacionesSeriadas/EstudiosHistoriaEconomica/Files/roja73e.pdf. 
to stay just with three duros. NO WAY!! You not only had to feed the children but to dress them and pay rent and electricity...I had four children.... The next year I got a stand in the public market to sell the meat offal from the butcher shop. I sold, tongue, heart, tripe...."

Figure 19: Patro in the market stall

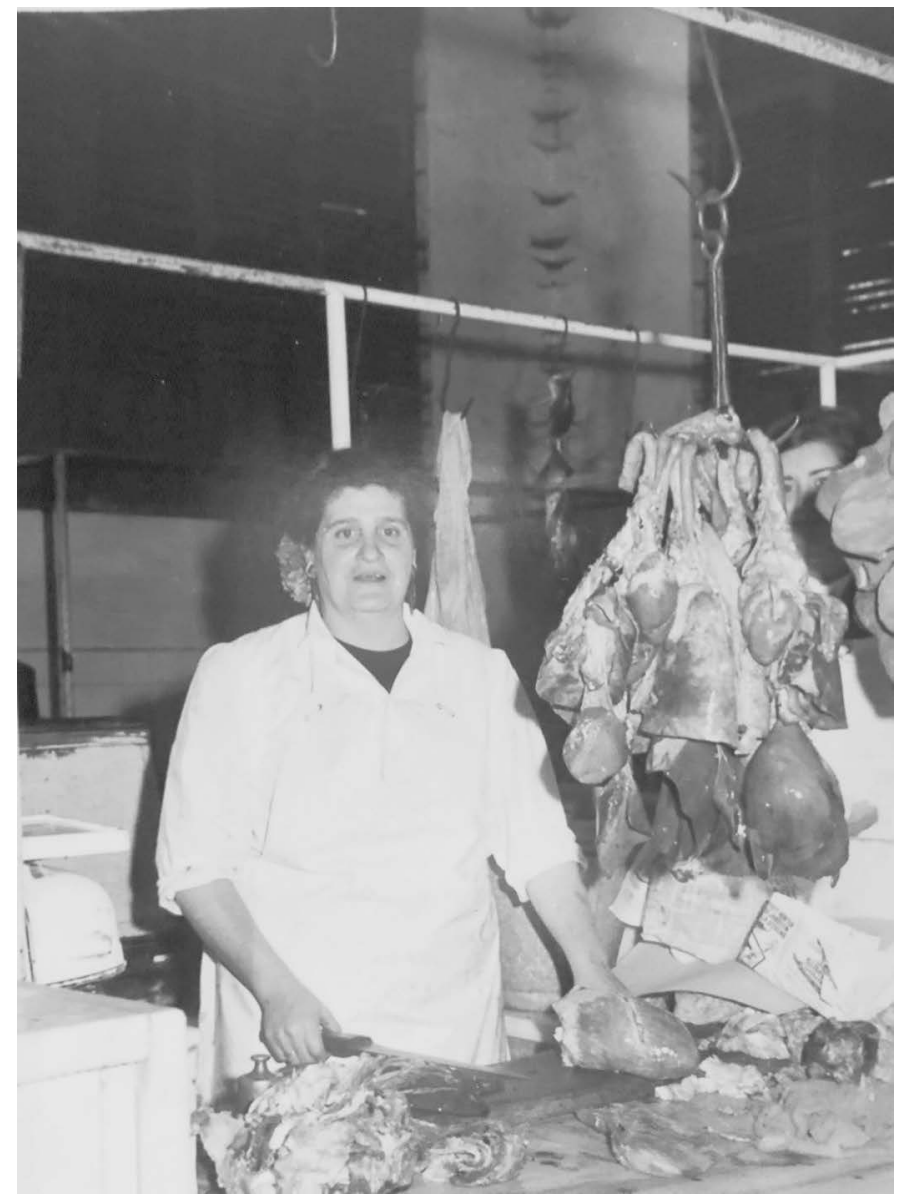

I remember my aunt at her stand in the public market, dressed in bloodspecked white, holding a butcher knife in one hand and a gigantic cow's heart, our dinner that night, in the other. Hers was in one of two rows of stands occupied by other women also dressed in white, hawking their wares to the passersby. At various times on my aunt's marble counter you would find squishy brains resting 
next to rubbery pigs' feet or a gigantic, mute, fleshy tongue. Entrails draped from meat hooks behind Patro's smiling face. Amid the animal carnage, Patro was in her element, selling to the women, like my mother, who needed the cheap meat to flavor the soups, to feed their growing families from their husbands' meager wages.

Figure 20: Empty market stalls

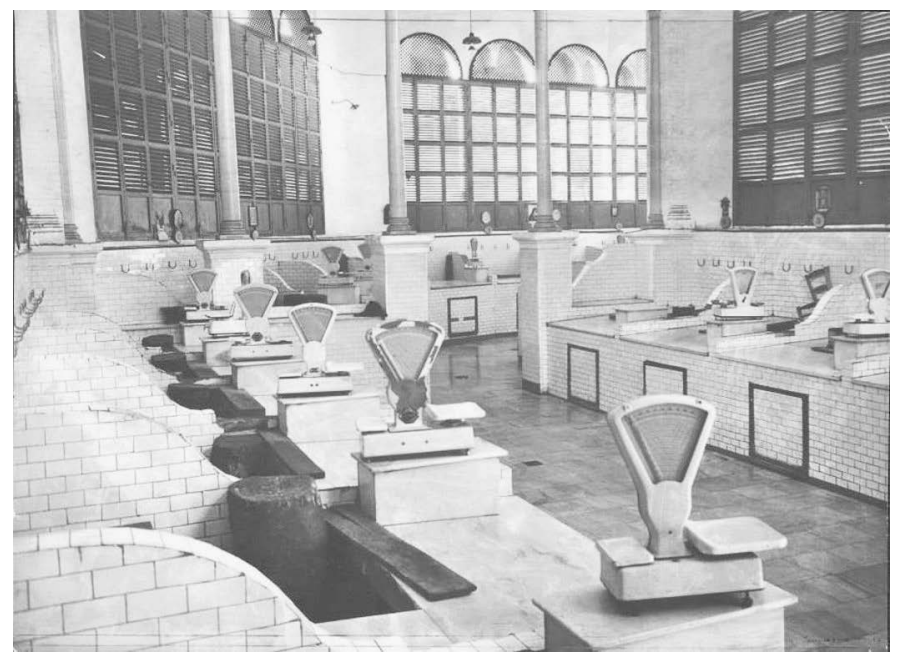

The offal sellers were all women. The butchers were all men. This unquestioned hierarchy was indicative of the way working class women under Franco were relegated to the helping class. Having recently emerged from the worst of post-war deprivation, these women were in no position to question this hierarchy. They were just happy to have their own little white tile stalls and the castoff pieces of meat to sell. What looked like a scene from a horror movie was their sanctuary. Here they enjoyed a lively fellowship amongst themselves and the housewives who came daily to haggle. 
Figure 21 (left): Patro and two others at the market stall

Figure 22 (right): Patro cutting meat
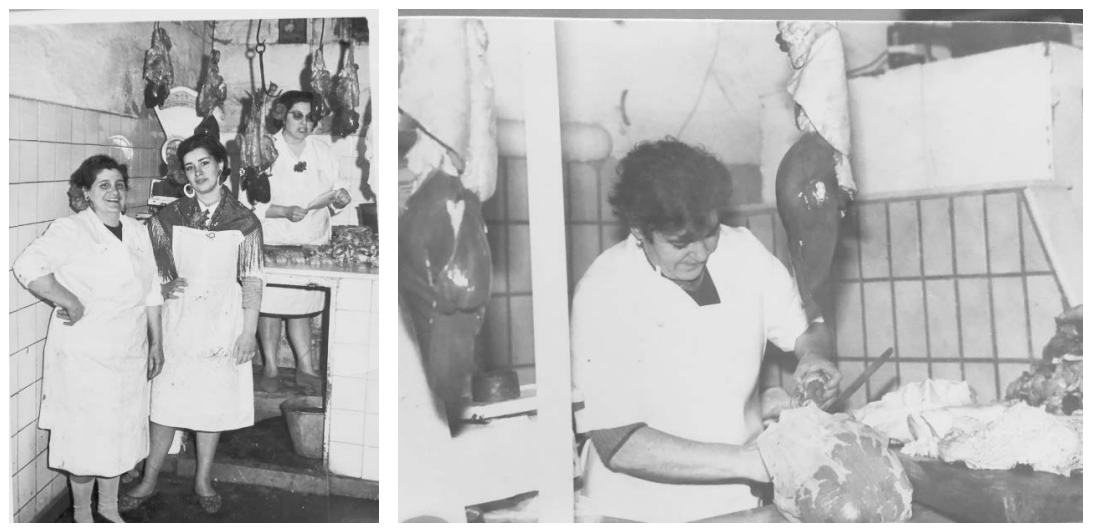

\section{Butchery Business}

The butcher shop that belonged to Patro's adoptive family, the Escribanos, ended up in the hands of her older brother, Felix. "When my uncle died...my aunt left the butcher shop to her sister," Patro shared. "Of course, she was not going to leave it to me!! You understand? And then, she hired my brother Felix, paying him thirteen pesetas a day.... One day she showed up at the butcher shop and said... 'Felix, I want nothing with this butchery, you can have it!' That simple! And then Uncle Paco [her younger brother] arranged the paperwork and the butchery went entirely to FELIX [she declares with an intense look into my eyes].... And me, the one who grew up with them...[pause] what do you think of that?"

This is particularly painful for her because when she asked Felix to supply her with offal to sell in the market, he at first refused. No, that was not a job for his sister. But Patro begged and begged him until he finally relented. She needed him to provide the offal meat for her to sell in her little stall to be able to support her family.

Without a source of steady income, women had to rely on the charity of men. For Patro, this was not an attractive option. Once her brother finally agreed to supply her with his discarded scraps, she was on her way: "I was a good seller. Everyone got to know me. Some days my sister Dolores would come down and other days she would help with the children. In the end, I do not know who said...I do not know if it was your grandmother or Aunt Nieves, 'Go ahead and bring cousin Aurora to take care of the kids'... and that's how your mother came to live with me." 
My mother was thirteen years old when she moved in with her first cousin Patro, a widow with four young children. Theirs turned into a happy relationship as my mother would be living among family rather than being a domestic servant in the houses of strangers, while my aunt, a young widow, would have someone she trusted looking after her children and the household while she worked in the market. They lived on San Isidro Street in a centrally located neighborhood behind the city's patroness, Virgin of the Sorrows Basilica. Patro and her four children would have qualified for public housing as a large family, but the paperwork got lost after her husband died and she never applied again. The San Isidro home was always open to family, neighbors, and friends from near and far. It was in that living/dining-room that I stood in tears while my aunt pierced my earlobe on a spring afternoon in 1969.

The apartment was small, located on the top floor and arranged around a central patio where the windows faced inward. "So much hard work," she reflected, "...and your mother with the children there. Then I came, we sewed, we made dinner, we did so many things together. Look...the house was like this, you went in and there it was, the dining room with a balcony. And our uncle from Noalejo made me a bar from side to side to hang some drapes that the kids said was the theater curtain...but it served us better as a divider. When the kids got dressed and undressed, we would draw the curtain and split the room. And then from the same room [to the right] there was another small room and there is where I put Grandpa [her father]. Grandma [her mother] had occupied it the same before him...until she died there, while your mother lived in my house too. You know that I did not grow up with them [her biological parents, the grandparents of her children] and yet both died here with me.... You realize what...what life is all about. When Grandma died, Grandpa was living with Aunt Dolores [Patro's younger sister]. Aunt Dolores went to the butcher shop on San Juan de Dios Street...and asked me, 'Can you take care of Papa?' 'Oh, well, then send him to me,' I said, and Grandpa came to live with me, and I put him in that small room."

After twenty years of working in the market, raising four children, and caring for her ailing parents, Patro was beginning to get sick. "I was exhausted. Papa was always getting up in the night. 'Niña, turn on the light.' 'Papa, what do you want?' 'Turn on the light. I have to pee.' After that I would return to bed...in a little while again, 'NIÑA...!' I do not know how much time in between...in a little while....again I got up. 'NIÑA...!' Then, I would come back from work and Patrico [her oldest daughter] would tell me, 'Grandpa is waiting for you with soiled hands from wiping himself....' I would wash his hands...He did not want to eat until I came back from work.... Well, this happened day after day.... Then, well, then Uncle Antonio and Aunt Dolores came to help take care of Papa...'so you can sleep.' But Papa would say, 'no, no, no, my PATROCINIO only!' And I was right next door where I have the 
bedroom. Well, I would not sleep either. Then I fell. They told me it was a bad heart. I needed to stop working and rest."

Patro was forced to retire. She eventually regained her health but didn't return to the market. She still cooked and cleaned and even helped her seamstress daughter Patrico with some sewing. Keeping track of her four children and many grandchildren became almost a second job.

In today's world, a four-year-old girl who was freely given away by her parents to a wealthier, childless family might be expected to have issues. Another girl, only thirteen, lent to a new widow to help her raise four children, might also be expected to harbor some resentment. But this was not the world in which my Aunt Patro and later my mother, Aurora, grew up. Their world was one of civil wars, dictators, and years of hunger, where the suffering of working-class women was part of the collateral damage.

Far from feeling sorry for themselves, these women learned how to survive in a world in which their men were conscripted, co-opted, and often damaged. They cooked and sewed and cleaned house. They raised families and took care of the elderly. And they worked in the markets, stalls, and shops to make the little bit of money that kept their families housed, fed, and clothed. These working-class women were more practical than political, but their underlying fortitude made a statement all its own. The lie that women were the weaker, more fragile sex was hard to accept when growing up with working-class women like Patro. The strength they showed was not lost on my generation, nor was the blatant injustice they suffered at the hands of men and a patriarchal regime. The implicit lesson that these women taught us was that only we knew how to provide for ourselves.

Patro died on October 22, 2018, of a stroke. One hundred and one years old, sharp as the knives she used to cut the fibrous cow's heart in the market stall so many years earlier. My mother, who she liberated from a life of penury in the village, still lives. I sit here writing these stories because of them. 